\title{
テレビジョンカメラを使用した 自動引張試験機の開発
}

(昭和54年 8 月 13 日 受理)

\section{三橋 健八*1 伊藤 裕幸*2}

\begin{abstract}
要旨 本報告の目的はゴムに代表される粘弾性体のよらに破壊に至るまでの変位量が5〜10倍にも達す る大変形試験に执いてダンベル状試験片の標線間伸び率を試験片より離れた位置からテレビジョンカメラ (TV力メラ)を利用して自動測定する方法交示するのである。

$\mathrm{TV}$ カメラ利用して時々刻々変化する標線間長さを自動的に測定する本装置の大きな特徴は TVカメラ の面走查を利用して試験片表面の標線と標線以外の部分の明度の差をTVカメラ出力信号として取り出し標 線間隔をデジタルデータに变換する方法と，TVカメラの視野から試験片のみの信号を取り出すダート回路 技矢とを組合わせる方法である。これにより恒温槽内の自動引悙試験を可能にし，同時に測定精度を（パラ ツキ1/3に減少) 向上させ, $1 \sim 3$ 名の省人を可能にするなどの大きな効果を上げることができた. 更に, 本装

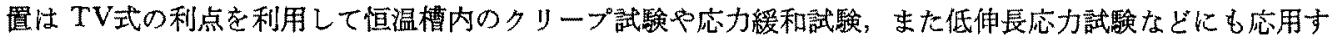
ることができる。
\end{abstract}

\section{1. 緒言}

引張試験は各種材料の最も基本的な力学的かつ機械的 特性を評価する方法であり，その材料の破髙特性仕もと より破罗に至るまでの変形特性や破壊までの変形エネル ギーまで测定でき，その現象論的解析も進んでいること 恃周知のとおりである。

特に最近のように材料開発や品質管理に引張試験が重 要視され，その使用頻度が高まるにつれ測定結果に対す る精度向上や試験生産性の向上に対する要求がますます 増加の一途を辿っている.

本報告は特にゴムに代表される粘弾性体のように破壊 までの試験片の伸び率が 5 ～10倍にも達する大变形試験 において特にその効力を発揮する新しい型の引張試験機 の開発結果を報告するものである.

\section{2. 新しい引張試験機}

\section{1 試験機開発のポイント}

新しい試蝜機を製作したり，徒来の装直を改良したり する場合，我々使用者は盛り沢山の仕様を考え複雑な装 㯰にしてしまら傾向がある。

一方，その装置を使用する場合には次の配虑をする。

\footnotetext{
*1 横浜 ニ゙ム株材料研究部

（元254 神奈川県平塚市追分2-1）

*2侏フジテレビジョン技術部

(テ162 東京都新宿区市々谷河田町 7 番地)
}

（1）測定結果が実製品に見られる現象と相関している こ

(2) 测定結果の再現性が良いこと.

(3) 従来の測定結果と相関のあること.

(4) 試験生産性の良いこと。

(1) 従来の作業方法を大幅に变えないこと.(例え ば，試験片などの作成方法が従来と異なると，モ 一ルドなどの変更が必要になる。)

(ii) 試験機のメンテナンスが容易なこと.

(iii) 試験機の故障が少ないこと。

(iv) 测定結果の整理が容易なこと.

（5）試験機の価格が従来より安価なこと.

以上のように我々使用者の要求は勝手なものである。 さて, 新しい試験機が引钱試験の場合, その要求は次の点 に絞られる.(なおっここで試験片とはJIS K 6301の3 項 に記載されるダンベル状 1，2，3，4号試験片を示す.)

（1）試験片の伸びを標線間の真の伸び率として正確に かつ自動的に読み取ること。

（2）試験片の引張荷重を自動的に精度良く検出できる こと.

（3）試験片作成準備が容易なこと

(4) 試験片を試験機に取付けたり，取り外したりする クランプ作業が容易なこと.

(5) 測定結果の整理が容易なこと.

これらの要求の中で特に注目される点は試験片が試験 により大㚆形しタランプより滑り出て，試験片標線間の 
正雅な伸び率を測定することが困難な点である。

標線間の正確な伸び率を自動的に測定することは测定 精度向上や測定者の疲労の減少, 同時に試験生産性向上 による省力化などのいろいるな間題点を一度に解決でき る非常に大きな関門であり，従来から多くの人々の改善 の目標になっていた ${ }^{(228)}$.

\section{2 テレビジョンカメラを使用した引張試験機の開発}

自動引張試験機の特徴の一つに引張荷重をロードセル で取出す点や，測定結果の整理にコンピュータを利用す る点はすでに多く報告されているので，本報告の特徴で ある試験片の禋線間伸び率自動測定方法について詳しく 記述する 2 (20-36).

近年のマイクロコンピュータなどの発展がデジタルデ 一タの処理技術を著しく容易にしている点法周知のこと である，したがって本報告で紹介する装膡も例外ではな く，試験片の標線間膈を確実にデジタルデータに変換で きればその後の処理については容易であり，かっ100\% の信頼性を持って試験片の伸び率を知ることができる。 仮に测定結果に誤まりや不確奏性の問題が生じたとして も，それは常に長さなどの実際の物理量をデジタル信号 に変换するインターフェースと呼ばれている部分の問題 であるので，本報告ではその問題の部分に相当するテレ ビジョンカメラ (以後 TVカメラと称する)を使用して標 線間長さを電気信号に変換する技術について特に詳しく 述べる。

この閉発内容を大別すると次の三項目に分類される。

(1)引張試験機本体の改良

12）TV カメラ自身の改良

(3) TV カメラ出力信号の処理方法

引張試験機本体の改良とは，TVカメラ視野内の試験 片伸び範囲が均一な照度になるように蛍光灯などの照明 を取付け，同時に試験片の背景は試験片のベースの明度 に合わせた色(例えば，試験片が黒いゴムの場合は背景 む黒色にし，長さを正確に測定するための長さ基準板 (標線閒隔の整数倍長で標線とほぼ同様の明度を持つ板) を試験片の近傍でかつTVカメラの視野内に取付ける内 容を示寸もので，本体の簢単な改良である。

TVカメラ自身の改良とは, 試験片背景を通常黒くす ると先に述べたが，クランプ金具などの反射部分がどう してもTVカメラの視野に入り TVカメラ自身の AGC (Automatic Gain Control) 機能が最明部で動作してしま らので，より低照度の標線の信号性著しく低下してしま い標線信号を取出すことができなくなる。これを防ぐた めに TVカメラ内の $\mathrm{AGC}$ 信号源として全視野を用い
ず，特定部分のみを基淮として選択するよらなゲート回 路を付加する TVカメラ自身の改良が必要となる。

$\mathrm{TV}$ カメラ出力信号の処理方法については測定原理と 共に以下に述べる.

まず，図1の全体の構成図によりシステムの概要を説 明する，試験片は従来と同様に試料ゴムシートより打抜 きダンベル状試験片を使用する。従来と同じ方法でベ ンチマーカを使用して政線を付け，試験機にクランブす る. 取付けた試験片は長さ比較用として試験片近くに設 置した長さ基準板と共にTVカメラで撮像し，その捕え た試験片の標線間の長さ信号と基準長さ信号をデジタル 信号の形で諭理演算回路に入力する．荷重值はロードセ ルで検出されアナログ, デジタル変換器でデジタルデー 夕に変換されて諭理演算処理回路に入力する. また，そ の他論理演算回路には試験片番号や試験片厚さ寸法など の内容も入力される. 標線閒伸び率や引張応力汇試験中 時々刻々表示され，同姷に設定モジニラス値も表示する ことができる.

データ真偽判定回路はTVカメラ視野の中に異物や作 業者の身体の一部が入り込んだ場合に誤ったデータが出 力されないよ 5 に長さ基準板からの標線相当信号の数が 一定である事它チェックし，更に毎走查ごとに試験片標 線間データを保存し，次の回の走查で得られた值と比較 し，データが走查のたびごとに一定の割合で増加してい ることを確認し，データの真偽を判定する回路である，

遅延データとは試験片が破断した時，破断寸前のデー 夕を利用するために一回前の走査データを保持する心要 性から生じたすのである。

TVモニターはTVカメラからの動作を確譛するため のもので TVカメラ視野やレンズの焦点が正しいか否か を確認する事が主な目的であるが，更にTVモニター上 に数字や文字を表示することができるのでデータ表示器 と兼用させることもでき，重要な役割をはたす。

以上，原理的な構成説明したが，奏際には論理演算

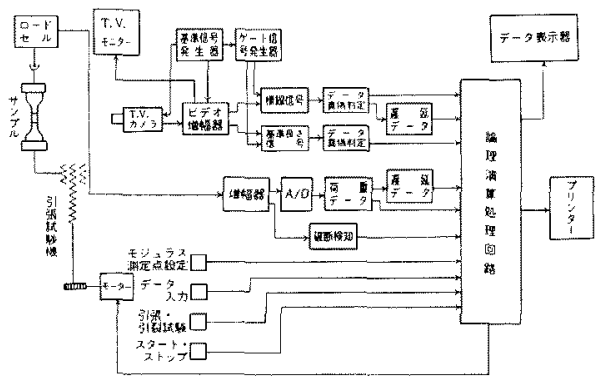

汹 1 全体の棈成戍 
処理部分にマイクロコンピュー夕などを利用すれば，デ 一夕直偽判定回路によるチェックや䢭延データの保存な どはコンピュータのプログラムで処理することもでき 万.

次にTVカメラによる長さ測定の原理について記述す る. 図 2 にダンベル状サンプルに 2 ケ所の標線をつけた ものを TVカメラで撮影した様子を示す，TVカメラは 左から右へ線走查を繰返し，これを上から下まで少しず つずらしながら反復するので TVカメラ出力には(A)のよ 5 に光の反射率の高い標線部分から大きい振幅の停号が 得ら九る，通常 TVカメラは一秒間に30林の画面情報を 送り出し，また一枚の画面は約500本の走查線から成立 っている. 標線以外の部分にはノイズ状のレベルの低い 信号が乗っているので，これの影響を除くために一定の レベル $\mathrm{E}_{1}$ より大きい振幅のものだけを取出すと(B)のよ らなデジタル信号を得ることができる，この信号の電気 的時間間隔 $\mathrm{T}$ は試験片の標線閒の長さ Lを走査する時間 間隔に等しいから圾験片の標線間隔 L は電気的時間間隔 Tに直換されたことになる。

更に実際的な波形処理方法について図 3 で述べる．先 の図 2 で圾試験片標線一個に一つのパルス信号が相当す るように述べたが，実際には TVカメラの解像度が良い のでTVカメラ出力には(A)のように禋線一個に対して 2 本から10本の走查線によるパルス信号が発生する．図 4 は実際の TVカメラ出力であり(A)の状態を示している， 写真上部の矢印の位置が試験片の標線部を示し，標線以 外の部分より高いレベルのパルス信号が得られているこ とがわかる.このパルス信号からレベル $\mathrm{E}_{1}$ 以上を取出 した後に走查周期と同期したサンプルフンドホールド回 路又は再トリガー型ワンショットマルチバイブレーター

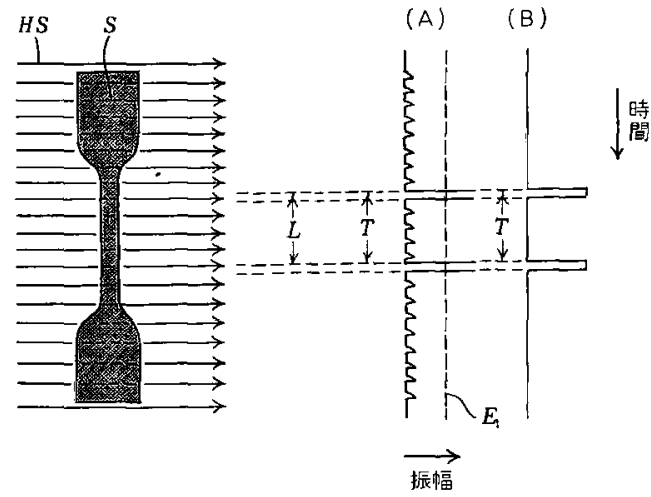

図 2 TV カメラ現像モデル図
を通すことにより各標線グループごとにまとまった(B)の よらな信号に変換することができる，更にこれを T夕イ プフリップフロップにより(C)のように標線と標線の間に 及ぶ幅 Tを有するゲート信号に変換しここのダート信号 により一定周期のクロック信号(D)をゲートすると標線間 隔に対応したパルスの数を有する信号(E)を得ることがで きるので，この信号をカウンターに入れて計数すれば， 試験片の標線間距離をパイナリーデータ又はバイナリー コーデッドデシマルデータなどのデジタルデータに変換 することができる．図 5 は図中(B)の状熊，図 6 は(C)の状 態を示す実際の TVカメラ出力である。

次に TVカメラの視野の中から引張試駼機で使用され るクランプ金具などのような金属部分による光学的影響 を受けずに目的とする標線信号を確実に取り出す技術に ついて記述する. 図7で $M$ は $\mathrm{TV}$ カメラの視野を示 し，1 は試験片，2 2 はクランプ金具を示す。論理回路技 術により画面を電気的に縦に $e-e^{\prime}, b-b^{\prime}$ で曲まれた部分 に分割し，これをサンプルエリアと呼ぶ．更に標線エリ

(A)

(B)

(C)

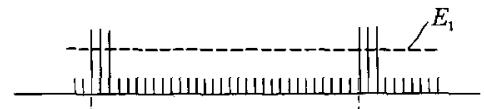

(D)

(E)
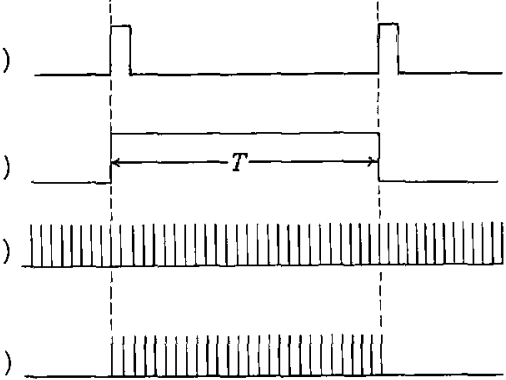

図 3 実際的な波形処理方法

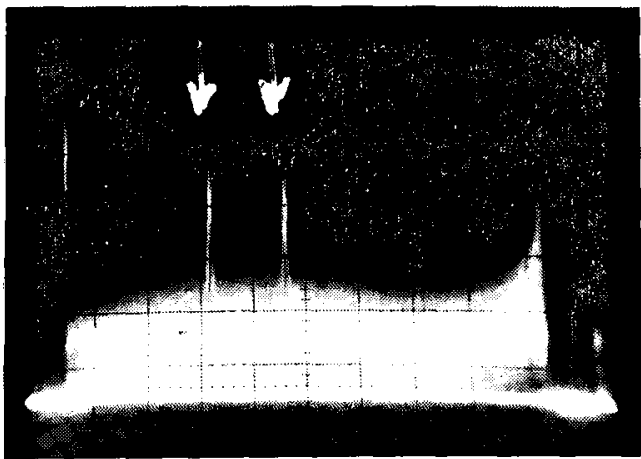

図 4 実際の TVカメラ出力状感(図 3 の(A)に相当) 
アとして $j k l m て ゙$ 囲まれた部分を分割するが，標線間隔 は時々刻々と移動するので標線エリアもそれにしたがっ て移動せねばならない。このため，クランプ金具に縦方 向測定範囲案内板を取付け，この部分を別に縱のゾーン

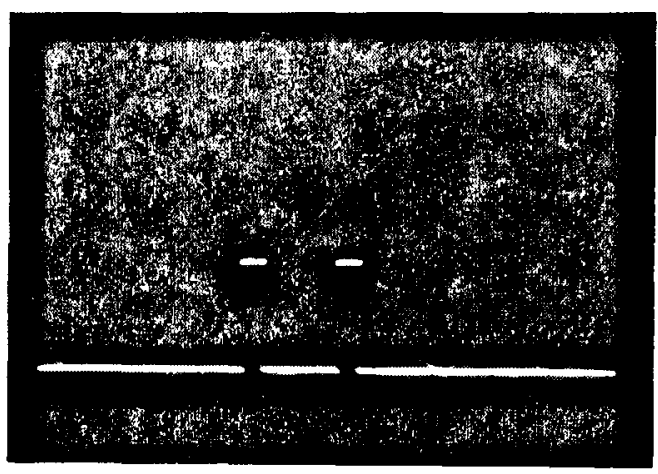

図 5 実際の TVカメラ出力状態(図 3 の(B)k相当)

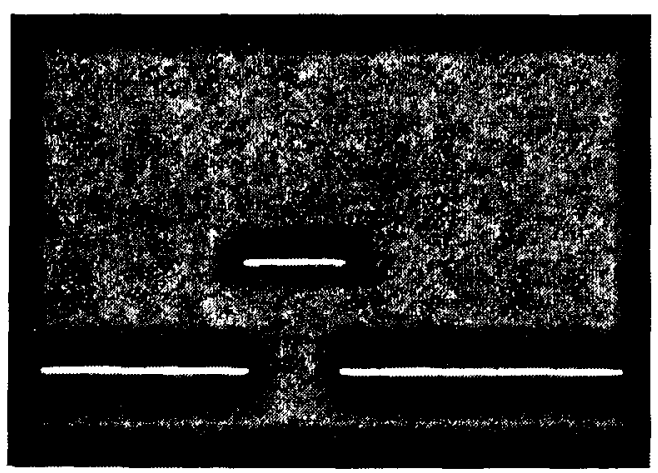

図 6 実際の TVカメラ出力状態(困 3 の(C)に相当)

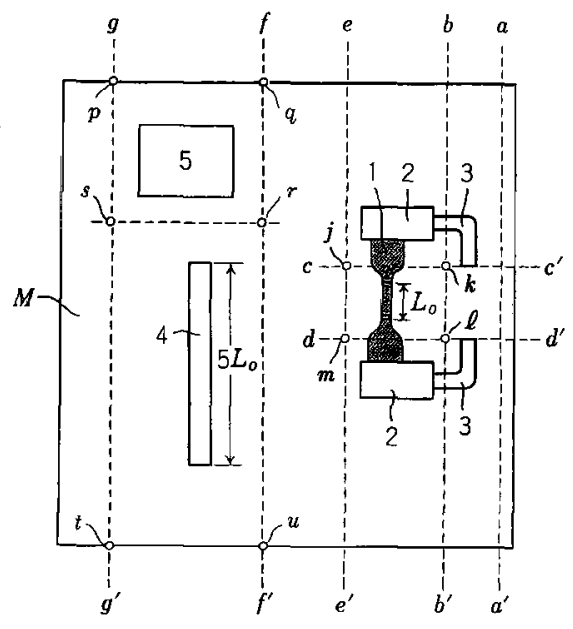

図 7 TV カメラ視野ゲート回路技峏 $b-b^{\prime}, a-a^{\prime} て ゙$ 取出して上の案内板の下端に相当する信号 で $c-c^{\prime}$ の位置を決め，下の案内板の上端で $d-d^{\prime}$ の位置 を決めればゲート回路技術により時々刻々標線を追ら標 線エリア $j k l m$ を得ることができる。標線エリア $j k l m を$ 得る他の方法として試験片の標線及びクランプ金具が引 張試験開始と共に下向に移動する速度を測定しておき， その速度を利用して標線エリア $j k l m$ を純電気的方法に より試験開始後の㭙間と共に拉大する方法もある.

更に，機械的案内板 3 加ら得られた信号を基にして前 述した電気的デーンダート信号を引張時間と共に実䏅の 標線部分のみ追跡するよ5に狭めて作れば，特に大変形 する試験片の場合, 変形の增加と共に起こる試験片の変 色や異常反射などの悪影響を無視することもできる.

また，視野Mの中にはサンプルエリヤと標線エリヤの 他に縱のジーン $g-g^{\prime}, f-f^{\prime}$ で囲まれた部分を設け，更に 上下に 2 分して上の pqsr のゾーンには明るさの基準板 5 を設け，また下の stur のゾーンには長さの基準板 4 が 設けてある.このエリヤを基準エリヤと呼ぶ. 明るさの 基準板とは，TVカメラ信号の一定レベル以上の部分を 標線信号として取出すと前述したが，試験片表面の照度 が変わると信号レベルも変わるため，TVカメラのAGC の動作の基準となる標隻反射率を持った板を示す。この 明るさの基準板の反射率と試験片標線の反射率とをほぼ 等しくしておくことにより TV カメラの AGC機能が引 張試験機のクランプ金具部分などで異常に動作してしま らことを防いでいる. また，長さの基準板とは，引張試 験前の試験片標線間長さ $L$ 。の整数倍(計算上の便宜のた め整数倍が好ましい)の長さを持つ板を示し, 引張試験 開始後は基準長さとの比例計算により標線閒の真の長さ を得るのに使用する。これ圾試験片とTVカメラの距離 が変わってむ較正なしで標線閒長さを测定できる利点の 他に，通常の工業用 TVカメラでは偏向ひずタと称され る走査線の間隔が不均一であることによる測定誤差や電 源電圧の大幅な変動などによる測定愦差をキャンセルす るためのるのである. 以上の特徴を持つ基準ェリア内の 各板は実際には一枚の板を兼用して使用することもでき る.

次にTVカメラによる測定の利点を更に発展させた一 例として複数本の試験片の引張を同時に測定する方法に ついて記述する．図 8 は TVカメラの広い視野を利用し て同時に三本の引張試験を行う場合の解析図である。こ の場合, 引張荷重検出のためのロードセルは各試験片ご とに必要であるが, 試験片下端クランプは共通のクラン プ金具一個で良い．まず縦方向の各試験片のゾーンを決 
めるために TVカメラの水平走查基準信号 $(\mathrm{G})$ を( $\mathrm{H}) ，(\mathrm{I})$ ， (J)，に示すようにそれぞれ $T_{a} ， T_{b}, T_{c}$ 時間遅延したゲ 一ト信号を作り， $z_{1} ， z_{2} ， z_{3}$ に示寸各試験片領域をゲー トする，横方向は共通のソ゚ーン ZV でゲートするが, 試 驗片が時々刻々下降するためゾーンを下降に合わさなけ ればならない，したがってゾーンZVに相当するダート 信号(0)を得るには，その始端を前述した上部クランプ金 具から得る方法の他に図の上5に垂直走查基準信号(L)上 り $T_{e}$ 時閒荤延させ得ることもできる.ゾーン $\mathrm{ZV}$ の終 端は下部クランプ金具に取付けた案内板 $\left(3_{a}\right)$ からの信号 (N)から得るのが箱単であるが，前記と同様，純電気的に 作ることもできる．このようにダート信号(0)を得てカメ ラ出力に表わされる陚験片部分の信号(はをゲートすれば クランプ金具などの不要部分を取除き目的とする標線部 分の信号(P)だけを取出すことができる（なお，图の信号 (以は説明のため三本の試験片のうち一本についてのみ示 してある.)信号(P)が得られれば先に説明したのと同じ方 法で $(\mathrm{Q}) ，(\mathrm{R})$ を得て長さ信号を得ることができる. 試験 片が三本でもTVカメラは各試験片に対する長さ測定を 一画面の5ちで時分割して処理寸るので, 波形処理回路 を三組用意すれば一回の面走查ごとに三本分のデータを 同時に得ることができる。

\section{3 他の走查方式を使用した引張試験機の開発}

$\mathrm{TV}$ カメラ以外の走查装置を使用して試駼片から離れ た位置で標線間長さを測定できる装置について記述す る.

まず，通常イメージセンサーと呼ばれる固体撮像素子 を真空管式撮像管の代りに用いたものが良く知られてい る. イメージセンサーには線走查式と面走查式があり，

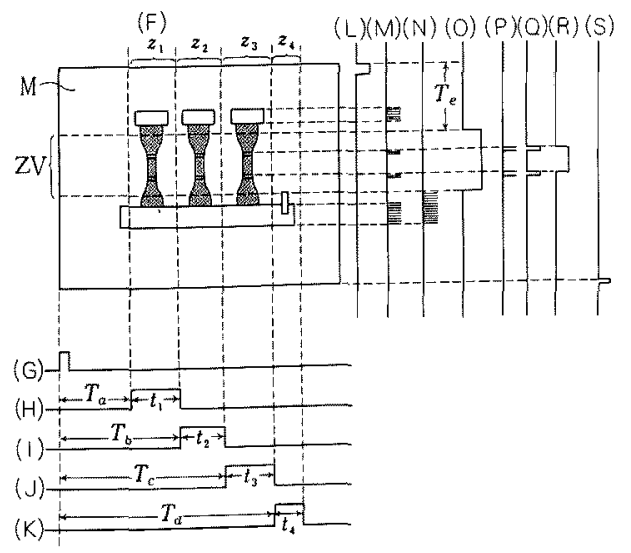

図 8 複数本引張りゲート回路技術
面走查式では従来の TVカxラに全く置き替るものと言 える，現在まだ価格の点で普及していないが，固体式で あるので悪環境での使用に耐え, かつ小型軽量であり， また構造上各走查素子が幾何学的整然と配列されてい るので従来の TVカメラにあった偏向ひずみの上らな走 查の不均一性はなく，また素子の寿命梳半永久的である から長さ測定などの目的に適している走查方式である。 次に線走查式は早く加開始されており分解能孔通常の $\mathrm{TV}$ カメのの 3 倍以上の素子を持っているが，これを引 張試験機に使用する場合は引張方向の線状の測定である ので正確に試験片上を走查しているか否かを確誌し位置 合わせするための装置を必要とする欠点がある.

更に，レーザースキャナーと呼价れるレーザー光線を 一定周期で線状に走查し, 反射光の明暗の差から測定物 の明暗デー夕を読み取る走查装直がある。この方式の利 点は線走查の位置が光として明確に対象物上に映写され るので位置の確認は容易である，次点としては装置価格 がかなり高価な点である。

以上いずれの走查方式を用いても前述したよらな全体 の出力信号から試験片標線部分のみを試験の進行に追従 して検出するゲート技術や信号处理方法は必要である。

総合的洘えると価格の点と被写体照度の大幅な変化 に対しても常に電子的に自動補正された一定レベルの信 号茂得られる撮像管式 TVカメラが当分使用されるが, 次第に固体走查素子を用いた装置に移行されるものと考 える。

\section{3. 結果及び考察}

図 9 は本装置の代表的な実施例である，写真の中で使 用している TVカメラは試験片の長さ測定のために特に 開発された高価な TVカメラではなく一般市販の工業用 のTVカメラを一部改造したものである. 既に述べたよ うに,このTVカメラの役割は, 試験片の標線長さを電 気信号に変換することである. 一方 TVモニターは試験 片を正確に捕えているか不かを判断する以外に図10に示 すように，種々な目的に利用されている，例元ば，自動 引張試験機の最大の問題点である異常値をそのまま試験 結果としてプリントアウトする点を防ぐために測定中時 々刻々変化する引張応力や伸び率の変化が急激に変化し た場合(試験片が破断した場合は除く)異常発生の警報を 出LTVモニター上にその異常内容の種類と原因を表示 させる。 また, 測定中の時々刻々変化する引張応力や伸 び率の表示やキーインされた試験片寸法や番号を表示す る役目も持っている. 
またここの装置によると測定中時々刻々変化する試験 片の引張応力や伸び率を自動的に読み取ることができる ので X-Y レコーダーに正確な応力一ひずみ曲線を試験 の進行と同時に記録させることができ，また，その変形 エネルギーも橨分值として正確に得ることも容易であ b.

図11は本装置を恒温槽付引張試験機に取付けた実施例 である. 周知のとおり恒温そう内での引張試験をダンベ ル状試験片で行う場合, 高温試験になるにしたがい試験 片がクランプより滑り出て正確な伸び率を測定すること が困難であった．従来これをりング状試験片を用いて自 動測定したり恒温そ5内にメジャーを入れて恒温そ5外 から目測する方法が使用されていた. しかしながら，こ れらの方法では試験片の破燷強さが真の引張強さとは異 なったり，伸び测定が初期に扔いて不正確になったりし て，高温での引張試験の必要性が叫ばれていたにもかか わらず，測定結果の信頼性に欠けるものがあった．本装 置を取付けることによりこれらの久点を補い，恒温そち 内での引張試験を自動化できるだけでなく，既に報告さ

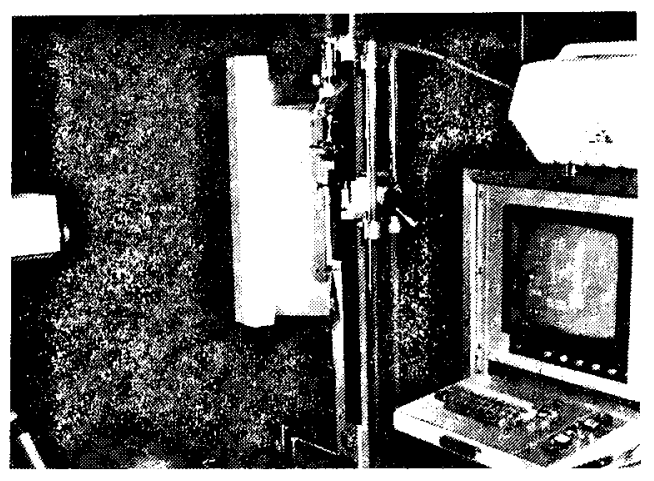

図 9 TV 式引張試験機の実施例

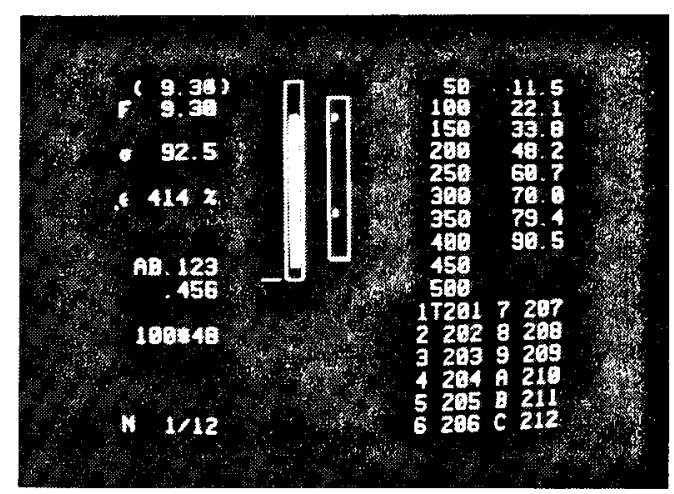

図10 TV モニターの実施例
れている ${ }^{37 \text { 42) }}$ 各種の武釦片自動供給装置を使用するこ とにより，ダンベル状試験片を利用した恒温そう付の全 自動引張試験装直を得ることができる。

更に，試験片の伸び率を正確に測定できる本装置の利 点を利用して恒温そう内での複数試験片のクリープ試験 や設定変位量まで変形させる応力緩和 試 験, また JIS K 6301 の第13項に記載される低伸長店力試験などに使 用され測定結果の精度向上はもとより省人効果などに大 きな力を発揮することができる.

その他，TVカメラのレンズを選択することによりあ る特定部品の変位や変位量を測定することもできるの で，それをビデオテープに収録することにより，测定後 に一画面つつの变形過程を解析することる容易である.

図12，13はTV式引張試験機を使用して行った測定結 果の一例である．図12は同一測定者による繰り返し再現 性を評価したもので，本装固の結果と従来のショッパー 式の結果とを比較すると測定結果のばらつきは本装值の 方が半減する，図13は測定者が異なった場合の測定結果 のばらつきの比較である.ショッパー式の測定結果は測 定者による依存度が非常に高いことが分かる．当然，本 装置の方は測定者による依存度は全くない，

以上を総合すると従来のショッパー式引張試験機と比 較して本装置の測定結果のばらつきは約 $1 / 3$ に減少する。 これは主に従来の方法による結果が測定者の熟練度に依 存したり，測定者の体調に依存する度合いが大きいため と考えている，言い換えると，TV 式引張試験機は測定 者の影響を受けず，かつ高精度な結果が得られる装置と

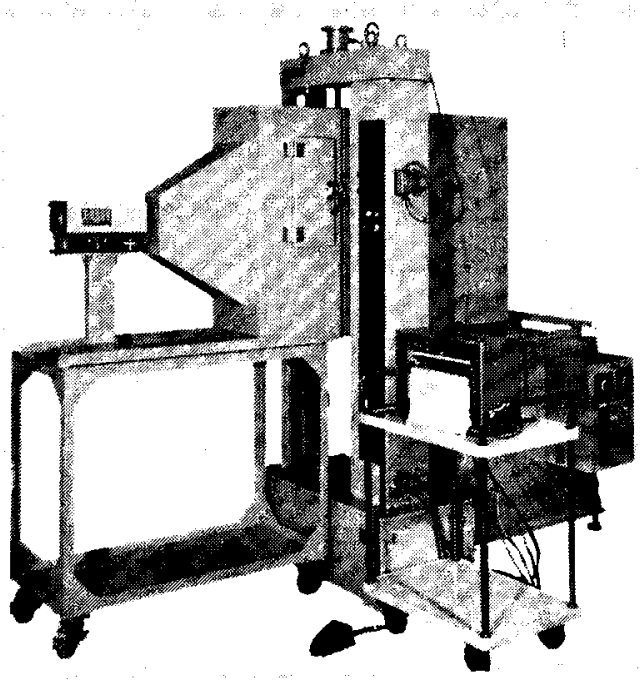

図11 恒温槽付 TV式引張試験機の実施例 
言える.

次に, 試験生産性について従来の装置と本装置との比 較を行ら。漹験量としては本装置の方が従来の装置を使 用するより約1.8～2. 2倍多い。これは主に伸びの測定作 業がなくなり測定者の疲労が少なくなった点と測定後の 結果の計算や整理がなくなった点である，更に省人效果 としては本装置では一名で最低 2 台のTV式引張試験機

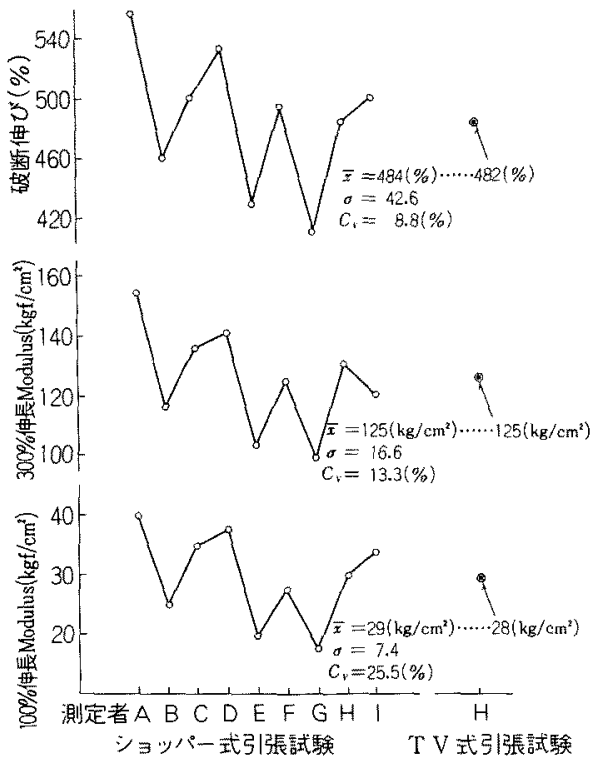

図12 テレビ式とショッパー式の湘定者による比較
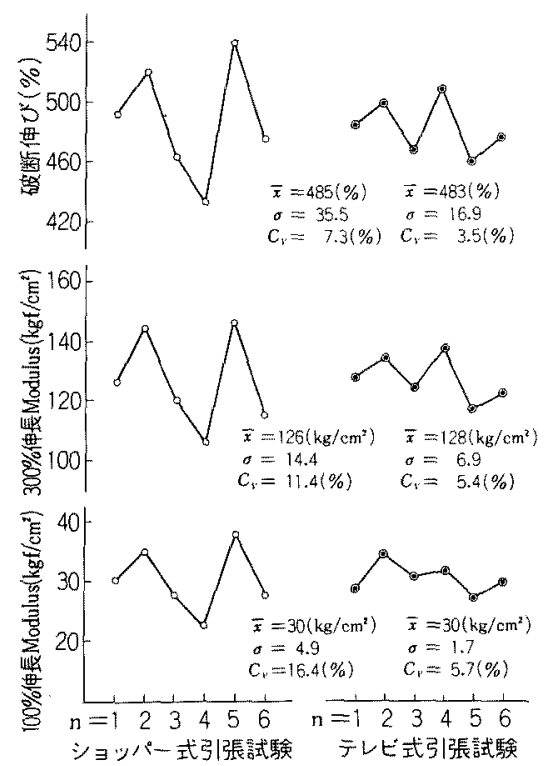

图13 テレビ式とショッパー式の試験結果再現性の 比較
を稼動させることができる。なた前述したように一台の 引張試験装置に 2 個のロードセルを使用し一度に 2 本の 引張試験結果を処理する場合も考慮すれば少なくとも1 〜 3 名の省人が可能になる.

作業性については，試験片の作成方法加ら標線の付け 方，また試験片のクランプ方法などの引張試験を行らほ とんどの手順が従来の方法と同様か，又は上り容易な内 容に改善してあり，TV 式引張試験機を使用することに より測定者の作業性を煩わすことはない，本装置を使用 して測定した試験本数は既に数拾万本を越えるが故障な どの問題多発生していない.

しかしながら，以上の特徴意保有している本装圈を使 用しても，その测定結果が実製品の強度とどのように相 関するのか。我々使用者にとって重大な関心事である。

少しでも実製品の使用条件に合わせようとして，今後 引張速度や試験温度を大幅に変えられる装圆の開発が要 求されるであろう，例えば一台の装置で低温から高温ま での温度変化はもとより低速から中速 (約 $1 \mathrm{~m} / \mathrm{sec}$ )までの 速度変化が可能な試験が予想される。一力 TVカメラに よる面走查では引張速度が中速から高速になるにしたが い碔験片の伸びを正確に読み取ることは困難になる。そ こで前述したTVカメラの水平走查周期の利用又は線走 查型イメージセンサーの忘用などによる高速化対策が必 要亡なる。

また，各種の色，明度を持った試験片に対する測定の 要求もある。色が明確な試験片についてはカラーTVを 遒入すれば解決する。一方色が測定中に変化する試験片 のよらに無色で中間の明度を持った試験片などは，T V カメラ出力信号を白とも黑とも判別できないので特殊な 標線用ペイントと光源やフィルターを利用するなどの光 学的手段による力法や，標線信号をアナログ要素別の多 数のデジタルデータとしてマイクロコンピュータに送 り，標線の持つ統計的性質を利用してンフトウェアによ り解析する方法などが考えられ色に対する対策名必要々 なる。

いずれにしろここれからの多用化する試駼の中で本装 置の活躍する分野怡いと考える。

\section{4. 結論}

TVカメラを使用して試験機より離れた位置からダン ベル状試験片の標線間長さを自動的にかつ正確に测定で きる本装置を開発することにより，

(1) 恒温そら内部での自動引張試験を可能にした.

(2) 従来の測定結果よりばらつきを后に減少するこ 
とができた。

（3）試験量を1.8〜2.2倍增加することができた.

（4）少なくとも1名〜3名の省人化学可能にした. などの大きな効果を上げることができた。

更に本装圆の利点を利用して恒温そう内の複数本試験 片のクリープ試験や応力緩和試験また低伸長応力試験な どの変位の测定に応用することができる。

その他，コンピュータ及びTVモニター表示を使用し た変形過程の解析や線走查装置を使用した中，高速引張 試験の変位の测定など広い分野での利用が期待できる。

\section{文献}

1) S. D. Gehman: Rubber Chem. Technol., 27, 503 (1954)

2) A. E. Eagles: ibid, 31, 673 (1958)

3) P. I. Donnelly: ibid, 36, 68 (1963)

4) Y.S. Zuev: Soviet Rubber Technol, , 21, 39 (1962)

5) E. D. Farlie: Transactions I.R.I., 41, T237 (1965)

6) D. Bulgin: Rubber J., 148, 34 (1966)

7) B. Bennett: European Rubber J., 157, 14 (1975)

8) B. Bennett: ibid, 157, 46 (1975)

9) Robert John: British Patent 3,926,042 Wallace 社 (1975)

10) J. H. Griffith: ibid 3,435,231 Instron 社 (1969)

11) Robert John: ibid 892,432 Wallace 社 (1960)

12) C. Scott: United Patent 1,714,638 Scott 社 (1929)

13) T. O Paine: ibid 3,592,545 (1971)

14) R. J. Vodra: ibid 3,120,780 (1964)
15) W. J. Budd: ibid 3,803,907 Uniroyal 社 (1974); ASTM STP 553178 (1974)

16) I. Furuta: United Patent $4,031,746$ 日本合成 $\triangle(1977)$

17) W. E. Claxton: ib?d 3,826,902 Firestone 社 (1974)

18) T· Anderson: United Patent $3,421,819$ (1969)

19) 饭塚 清: 特公昭52-13436 日本光学

20) 岩本真輔：特公昭52-45230 岩本製作所

21）古田 勲：特開昭52-26888 日本合成ゴム

22) 古田 勲：特開昭52-26887 日本合成ゴム

23) 山脇 武 : 特開昭52-50280 三菱化成工業

24) 山脇 武：特開昭52-50281 三菱化成工業

25）相沢作衛：契公昭49-11986 原子力研究所

26) Monsanto 社力タログ(1975)

27) 日本科学工業社カタログ(1976)

28）大島準一郎：特公昭38-15194 島津製作所

29）三橋健入：特開昭52-151081 横浜ゴム

30）伊藤裕幸：特開昭52-120882 フジテレビジョ ン

31) 三橋健八：特開昭53-45589 横浜ゴム

32) 伊藤裕幸：特開昭53-55186 フジテレビジョン

33) 三橋健八：特開昭53-90981 横浜ゴム

34) H. ITo.: United Patent 4,112,746 (1978)

35）三橋健八：日ゴム協第44回研究発表会 3-4, 48(1977)

36)上岛製作所カタログ(1977)

37) 山田数昭：特開昭48-68294 日本製鉄

38）山田弘治：特開昭51-12178 島津製作所

39）山田弘治：特開昭51-34784 島津製作所

40) 田中勝㶾：特開昭53-22489 新日本製鉄

41) 林 信考 : 特開昭53-138779 ユニチカ

42) W. J· Budd: ASTM STP 553178 (1974)

THE DEVELOPMENT OF AUTOMATIC TENSILE TESTER USING TELEVISION CAMERA.

\section{Kenhachi MITSUHASHI (Materials Research Department. Yokohama Rubber Co., LTD., 2-I Oiwake Hiratsuka City Kanagawa. 254 Japan) \\ Hiroyuki ITO (Technical Department. Fuji Telecasting Co., LTD., 7 Kawada-Cho Ichigaya Shinjuku-ku Tokyo. 162 Japan)}

The object of this report is to introduce an automatic measurement technique for tensile tests by using a television camera to measure marking-to-marking distance for dumbbell-shapped specimens at a position away from the specimen.

Especially, this system is effective for visco-elastic materials, represented by rubbers which extend up to five to ten times until fracture.

The most significant feature of this system is the transformation of the positions of the markers on a specimen into digital data by utilizing area scanning of a TV camera. This system distinguishes bright markings from the dark surface of a specimen, and use the digital gate technique which enables selecting the data relating to the specimen without being affected by obstructions which come in sight of the TV camera.

This technique not only enables automatic tensile tests or creep tests in an oven and permits appilcation to stress relief tests and low stretch stress tests but also improves the accuracy and reproducibility of measurements with labor saving effect. 